\title{
RICHARD HOOKER AND THE LATER PURITANS
}

\author{
JOHN K. STAFFORD* \\ University of Manitoba
}

\begin{abstract}
Attention is usually drawn to the negative relationship between Richard Hooker and his Puritan opponents. Such concerns dominate the polemical landscape of the late 16 th and 17 th centuries. However, the extent to which later Puritans appear to converge on Hooker's epistemology and overall attitude to the place of reason, Scripture and sacrament is often overlooked. This paper consider some key affirmations from Richard Baxter, John Owen and Hooker's contemporary William Perkins. The paper concludes that in more settled times substantive agreement might have been found on issues that during the reigns of Elizabeth and James I were profoundly divisive including the question of ministry orders.
\end{abstract}

KEY WORDS: Puritans, Richard Hooker, Richard Baxter, John Owen, Reason, Holy Spirit

Students of Richard Hooker's Of the Lawes of Ecclesiastical Politie are familiar with the accepted position that Hooker primarily defended the Elizabethan Settlement and Prayer Book liturgy and that he did so as Whitgift's man on the intellectual front line of controversy. The polemical stance of the Lawes was not defined by Hooker's rejection of reform nor by any means a rejection of Calvinism itself, but by his characterisation of the Puritan interpretation of Genevan reform. In fact, quite the reverse. Hooker has been shown to stand squarely within a Calvinistic theological matrix though with a critical appreciation of the relationship between the English Church and Rome. It was this latter aspect of the Lawes, together with his characteristic appreciation for St. Thomas and the high value he placed on rational discourse in theological investigations that caused confusion amongst many of his Puritan contemporaries. This resulted in Hooker having to defend himself against the charge of Pelagianism and that he was not, in fact, a defender of the key reformation tenets of sola scriptura and sola fide. The Christian Letter published after the first five volumes of the Lawes, gives voice to such objections and concerns. Hooker's marginal notes disclose his exasperation at being misunderstood

* JOHN K. STAFFORD (PhD, University of Manitoba) is associate professor in Biblical Studies at Providence University College, within the University of Manitoba. His teaching fields are Introduction to the Pentateuch, Homiletics, History of Liturgy, and Interpreting Old Testament Narrative. 
on what to him, were such rudimentary matters-normally, Hooker maintains an even temper in the course of the Lawes, so that when he does engage in serious or impassioned polemic, it becomes a noticeable occasion.

Hooker took a generous stance towards his Puritan counterparts though it was never without reserve. This restrained magnanimity Hooker saw the Puritans as requiring to measure up to his quality of truth and conviction. The restrained magnanimity displayed by Hooker nevertheless required the Puritans to measure up to his quality of truth and conviction. The "better sort" were not harsh or unreasonable; the "better sort" were learned and to these he could appeal. Yet evidently they were few in number and Hooker refused to yield the initiative as to what counted as sound learning. And although he modestly pointed to is own "small learning" nevertheless he had a very secure grasp of his own gifts and rejected any notion that he should not take pleasure or pride in his own intellectual accomplishments under what he took to be the guise of false modesty. This was in response to the Puritan emphasis that human achievement was of little or no value in the sight of God since our best works were as filthy rags before him. In fact, Hooker made it clear, in ironic fashion, that such a Puritan understanding of Christian humility was actually a key example of human pride, the very core of human depravity.

In his book on Hooker's later reputation, ${ }^{1}$ Michael Brydon notes the great range of responses towards Hooker and the emerging respect for the achievement of the Lawes. Indeed it is the later use to which Hooker was put that attracts interest. Although Hooker was increasingly used as the classic defence of Prayer Book liturgy and as the Savoy Conference progressed it was clear that Hooker's scholarship was taken to be unanswerable in the face of Puritan anxieties about a Laudian cast to the Restoration. Brydon observes that establishment clergy used Hooker polemically in defence of the Restoration church as a way to "shore up their intransigency by refurbishing the leading figures of the past, Hooker being the most notable of these..." Despite the failure of the Act of Comprehension which, notwithstanding offers of an episcopate and kept Richard Baxter (1615-1691) committed to non-conformity, Hooker was increasingly employed as a virtually unanswerable source of canonical ecclesiastical truth. In fact, Hooker's polemical strategy of visiting on the Puritans the same accusations of pride $^{3}$ or theological and pastoral distortions of which they had accused others is exactly what Baxter discovered at the Savoy Conference. ${ }^{4}$ However, a considerable amount of time and

1 Michael Brydon, The Evolving Reputation of Richard Hooker. An Examination of Responses 16001714 (Oxford: Oxford University Press, 2006).

2 Brydon, Evolving Reputation, 91.

3 Pride as the original sin from which all others were understood to derive. To attack Puritans on the basis of their pride was naturally to accuse them of the very things they considered brought divine wrath in others.

$4 \quad$ Brydon, Evolving Reputation, $91 \mathrm{f}$.

PERICHORESIS 11.2 (2013) 
violent history stood between Hooker and the Savoy Conference. The sheer exhaustion of that history and the goals of national reconstruction were making their way into political life in terms of the Corporation Act and the re-ordination of non-episcopally ordained presbyters-a situation that is still upheld, for example, in the re-confirmation of those not confirmed with the episcopal laying-on of hands. But conformity was always a shared ecclesiastical and political agenda.

While the presenting problems of church offices, liturgies, the defining nature of the church and the validation of its ministers lay at the heart of Savoy, it is reasonable to ask if there was as much separating the parties as the ecclesiastical polemics suggest. Certainly, as Brydon notes, Hooker was at this time an unassailable authority for loyalist clergy. But is there evidence to suggest the Puritans might have conceded more than they were willing on the grounds of theology. I think there is. Despite the historical backdrop of the Civil War and the long memory of Reformation conflicts that energised it, the later Puritans argued a theology that could easily be found in Hooker in consideration of the papacy, the doctrine of Scripture, the role and place of reason, the doctrine of the Holy Spirit, and so on. The nature of Hooker's debate with Thomas Cartwright and Walter Travers stressed the categories of epistemology and biblical hermeneutics. Indeed, though Hooker defended the Prayer Book he was less concerned about tradition than he was about truth-indeed, he was pained that his critics should fault him on this. This shows up in his evaluation of the heresies of Rome in which there is no heresy where the foundations of the Gospel are not fundamentally compromised. This was viewed with dismay by the Puritans but it was in essence the same standard of truth he applied to them though he naturally held them to higher expectations of conformity since they were brethren in the same house. He acknowledged the impoverished learning of so many clergy but was yet pragmatic enough to believe that while the problem was of such longstanding nevertheless the church must do its work in ministry and proclamation. Therefore, while Hooker exalts the life of the mind he was realistic enough to know that a lively and sharp mind in itself was not a sufficient guarantee of Gospel faithfulness. And besides, the sacraments, for example, did not need to be intellectually dismantled in order to receive their benefits.

The question is whether the gulf that separated Hooker from the Puritans during his lifetime was always as deep as the conflict itself suggested. As Michael Brydon has argued, Hooker was being used in the 17th century primarily as a polemicist—he was the defender of Prayer Book spirituality and ecclesiasticum. Dissent now took place in a more conciliar context as at Savoy but the questions now shifted away from core issues of, for example, human reason, sacramental theology, and moved towards ecclesiological matters such as the role of the episcopate, the ordination of clergy and the old questions of ceremonial and liturgical action. Thus, even if the church made bishops the church, in Hooker's view, could also unmake bishops-there were ways to do this. Surely this might be an early step 
towards appealing to a Puritan conscience. We find Hooker reflecting on the whether the episcopate in individual cases could appeal to its divine ordering in any absolute sense.

... their Authority [of bishops] hath thus descended even from the very Apostles themselves, yet the absolute and everlasting continuance of it, they cannot say that any Commandment of the Lord doth injoyn; And therefore must acknowledge that theChurch hath power by universal consent upon urgent cause to take it away. ${ }^{5}$

... least [they] forget themselves, as if none on earth had Authority to touch their states, let them continually bear in mind, that it is rather the force of custome, whereby the Church having so long found it good to continue under the Regiment of her vertuous Bishops, doth still uphold, maintain, and honour them in that respect... let this consideration be a bridle unto them, let it teach them not to disdain the advice of their Presbyters, but to use their authority with so much the greater humility and moderation, as a Sword which the Church hath power to take from them. ${ }^{6}$

Further, ordination could proceed without the episcopal laying on of hands. This was not the usual manner of things yet sometimes there may be occasion where it could be permitted. Again, the tradition was to be honoured but could never be held absolutely. There were limits to episcopal authority and it was important to know where they lay. This did not compromise episcopal authority because he held that authentic life within the church ought to constitute the larger dimension of Christian experience and order.

For there may indeed be circumstances where ordination might lawfully proceed without a bishop that seems to reflect a measure of Calvin's autonomy of the Spirit. The ordinary means of ordination was the laying on of hands by the bishop, but Hooker thinks "That there may be sometimes very just and sufficient reason to allow Ordination made without a Bishop" ${ }^{7}$ because in reality, according to Hooker, the bishop did not exercise ultimate power in the church but rather "The whole Church visible being the true original subject of all power..."

There were for him only two "just and sufficient" reasons and neither was fatal to the normative governance by bishops nor "a lineal descent of power from the Apostles by continued succession of Bishops in every effectual Ordination". ${ }^{9}$ The first was the sovereign will of God to raise up, or identify, any person "whose la-

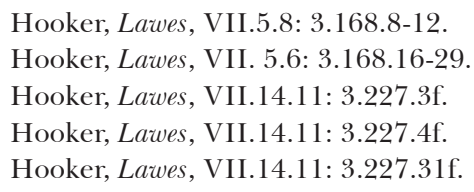

PERICHORESIS 11.2 (2013) 
bour he useth without requiring that men should Authorize them. But then he doth ratifie their calling by manifest signs and tokens himself from Heaven".

Hooker could hardly argue otherwise since this was exactly how the church traced its own Apostolic origins. Secondly, the church might find the need to ordain without a bishop. But he finds these to be the exceptions that prove the rule, and it is the rule that he finds necessary for order. It is also of note that he places presbyters in collegial relation to bishops, which must surely have been viewed as a conciliatory move in the direction Puritan claims to reform of what they considered the abuse of the episcopal office. Nevertheless, reflecting on the role of bishops as those "appointed to take away factions, contentions and Schisms," ${ }^{10}$ even if subsequent ordinations had a mixed character, "surely the first institution of Bishops was from Heaven, was even of God, the Holy Ghost was the Author of it". ${ }^{11}$ But as Douglas Stout notes, even though Hooker offered no elaborate structure for ministry, he held an exalted view of the episcopacy, not as a sign of the essence of the church but as a divinely instituted, though not absolute, sign of the church's fullness. ${ }^{12}$

In the Puritans' search for precise obedience to the doctrine of the Word of God, Hooker asserts that they have, ironically, ultimately lost sight of the larger Christian experience and shown themselves to be as subject to the law of sin and death as any man and equally idiosyncratic. Perhaps on the question of episcopacy, less determined minds might have found in Hooker closer points of contact. But in terms of the more profound questions for which Hooker is noted, the nature of law, the role of reason, his Christology, his trinitarian commitments, do the later Puritans display the same anxieties over Hooker as did their earlier counterparts? Can they be found closer to Hooker's mind set than the early battles describe?

Consider the question of the role of human reason. The Christian Letter expresses dismay at Hooker's apparent reliance on reason (quite apart from his use of Aristotle) not to mention his dense style of writing. For Hooker, this was a gross misunderstanding and failed to distinguish natural reason from right reason.

In his Pneumatologia, John Owen (1616-1683), one of the most prolific Puritan scholars, defended the integration of revelatory knowledge with human reason. Richard Baxter took a similar position. This is surely a departure from the position of Cartwright. The Christian Letter found everything qualified as "natural" suspicious. Hooker responded, "There are certaine woordes as Nature, Reason, Will and such like which wheresoever you find named... you suspect them presently as bugs wordes, because what they mean you doe not in deed as you ought

Hooker, Lawes, VII.5.10: 3.170.15f.

Hooker, Lawes, VII.5.10: 3.170.18-20.

Douglas Stoute, "An Anglican Understanding of Ministry and Church Polity in the 16th Century”, Consensus 12.1-2 (1986): 81.

PERICHORESIS 11.2 (2013) 
apprehend". ${ }^{13}$ Such lack of theological discrimination was actually harmful according to Hooker. It may be the case that any movement ordered around the purification of the existing order and filled with a sense of its own calling, is liable to fail to grasp both the need for its own purification and the difference between reform and radical deconstruction. In the case of the Puritan divines, amongst whom Hooker's own teacher John Rainolds is to be reckoned, there is found the same spectrum of abilities as Hooker's establishment colleagues.

Owen identified, as did Richard Hooker almost a century before, the crucial conditions under which he thought the church and Gospel would prosper. Owen writes: "In all the dispensations of God towards his people under the Old Testament, there was nothing of good communicated unto them, nothing of worth or excellency wrought in them or by them, but it is expressly assigned unto the Holy Spirit as the author and cause of it". ${ }^{14}$ He further declares "... in the New Testament, that whatever concerns the conversion of the elect, the edification of the church, the sanctification and consolation of believers, the performance of those duties of obedience which we owe unto God, with our conduct in all the ways thereof... that it is withal declared that nothing of it in any kind can be enjoyed or performed without his especial operation, aid, and assistance..." ${ }^{15}$ Owen points to the polemical issues that made the absolute rule of Scripture suspect:

... for let any avow or plead for the known work of the Spirit of God, and it is immediately apprehended a sufficient ground to charge them with leaving the rule of the word to attend unto revelations and inspirations, as also to forego all thoughts of the necessity of the duties of obedience; whereas no other work of his pleaded for, but that only without which no man can either attend unto the rule of the Scripture as he ought, or perform any one dutie of obedience unto God in a due manner. ${ }^{16}$

Now this sounds exactly like Hooker. For Owen, it had now come to pass that any desire to discuss the pneumatological essence of Christian belief was immediately called into question by charges of enthusiasm and the charismatic excesses of early Quakers and Brownists. ${ }^{17}$ Owen rejected the dichotomy of mind and Spirit as did

Richard Hooker, Of the Laws of Ecclesiastical Polity. Attack and Response: A Christian Letter, volume 4 of The Folger Library Edition of the Works of Richard Hooker, ed. by John E. Booty, gen. ed. W. Speed Hill, Folger Library Edition of the Works of Richard Hooker (Cambridge, MA: The Belknap Press of Harvard University Press, 1982), 5.17.23-26.

14 John Owen, Pneumatologia. Discourse on the Holy Spirit, volume 3 of The Works of John Owen, ed. by William H. Gould (London: The Banner of Truth Trust, 1966).

15 Owen, Works, volume 3, 7f.

16 Owen, Works, volume 3, 8.

17 The Quakers, also known as the Society of Friends, were founded in England by George Fox (1624-1691) in 1648. They were distinguished by their reliance on the authority of the inner light of religious experience rather than use of the Scriptures and sacraments. Their form of worship rejected orders of ministry and liturgical forms. The term "Quaker" was originally pejorative, describing their ecstatic experience during worship, but also referred to their call to 
Hooker. His Pneumatologia attempted to rehabilitate the place of the crucial role of the Spirit in Christian theology because the “... practical contempt of the work of the Holy Spirit being grown the only plausible defiance of religion, is also to be the most pernicious, beyond all notional mistakes and errors about the same things, being constantly accompanied with profaneness, and commonly issuing in atheism". ${ }^{18}$ To associate radical Puritanism with atheism was something not even Richard Hooker was prepared to do. So nervous was Owen about this that he condemns any hint of enthusiasm as worthy of his consideration. "Wherefore, as to enthusiasms of any kind, which might possibly give countenance unto any diabolical suggestions, we are so far from affirming any operations of the Holy Ghost to consist in them, or in any thing like unto them, that we allow no pretence of them to be consistent therewithal". ${ }^{19}$ Now all this sounds remarkably similar to Hooker's mistrust of private and personal disclosure of divine knowledge. Now that Puritans were part of the establishment with their demonstrated scholarship-their role in the KJV translation confirming that-Sebastian Rehnman reminds us that Owen's scholarship was at least as thoroughgoing as Hooker's, perhaps more so, being a close mixture of humanism and scholasticism. His devotion to the scholarly enterprise is exactly what drove Hooker. The same can also be argued for the sort of "great books" reading of Richard Baxter. ${ }^{20}$

Owen and Baxter were concerned to rebut the charge that authentic Puritan theology had abandoned rational inquiry in favour of a charismatic theology that elevated human experience as the touchstone of authentic Christian knowledge and claim to truth. The rational theological sobriety of Richard Hooker, John Owen and Richard Baxter was a response to both wild Puritan charismatic claims and an intellectualism which suppressed the very need for a pneumatic theology. Clearly, Owen was nervous that the gains made by Puritan dissent could be lost through failure to guard the mind and think Christianly. And this was a charge made often by Hooker namely - the early Puritans were ruining their own case. Owen shared the thinking of Richard Baxter who was also pre-occupied with maintaining a rational theological posture against charges of new revelation through direct spiritual experience. The doctrine of revelation did not demand rejection of the life of the mind but its transformation of it in the gift of the Holy Spirit. Neither Owen nor Baxter appear to deny the value of sound learning

"tremble" at hearing the Word of God preached. "Brownists" drew their religious inspiration from the Puritan Robert Browne (c. 1550-1633) who advocated congregationalist autonomy in opposition to the power and authority of bishops. Owen is not specific as to the source of the charges of "enthusiasm".

18 Owen, Works, volume 3, 8.

Owen, Works, volume 3, 13.

Sebastian Rehnman, Divine Discourse. The Theological Methodology of John Owen (Grand Rapids: Baker Academic, 2002), 29ff. 
wherever it can be found. Baxter's restraint, with Owen, is highly reminiscent of Hooker:

Quest. CLVIII: Should not christians take up with Scripture wisdom only, without studying philosophy and other heathens' human learning?

Answ. I have already proved the usefulness of common knowledge called human learning... 1. Grace presupposeth nature; we are men in order of nature at least before we are saints, and reason is before supernatural revelation. 2. Common knowledge therefore is subservient unto faith: we must know the Creator and his works; and the Redeemer restoreth us to the due knowledge of the Creator: human learning in the sense in question is also divine, God is the author of the light of nature, as well as of grace. ${ }^{21}$

So closely does this resemble Hooker it may be that Own is using him. A similarly remarkable feature is the extent to which Baxter continues his discussion of the Holy Spirit as the basis for epistemic certainty. So much is this the case, that it is necessary to consider whether a divergence occurs in later Puritan thought on the role of the Holy Spirit and whether the place of the Holy Spirit was as crucial to reformed thought in general as it is in the Lawes. In this limited study, it may be the case that the later Puritans had rediscovered the more balanced Calvin.

The Reformation emphasised the central role of the Bible, the salvation of the individual, the freedom to believe beyond the boundaries of ecclesiastical authority, and the desire (and necessity) to obey God constrained only by the pure word of God. This meant Puritan reform had to contend with an epistemology in which the Holy Spirit was a necessary key motive without which the role of the individual's faith would struggle for authenticity. Naturally, Hooker used this weak spot to his polemical advantage. William Haller points to this:

Belief in the eventual coming of the New Jerusalem and triumphing of the saints, too confidently proclaimed from the pulpit, led some men to grow impatient with the slow process of reform and to attempt the erection of the true church themselves in their own time. The doctrine, too convincingly set forth, of God's immediate concern with the individual soul and of the individual's aptitude for understanding what the Holy Spirit revealed through the spoken and the printed word, encouraged some to the idea that they need trust nothing so much as their own untutored notions even in defiance of sense and sound learning. ${ }^{22}$

By the mid-seventeenth century, the Puritan question of the human capacity to reason had taken a more refined position from that characterised by Thomas Cartwright who disputed any notion that human powers of reason could augment

21 Richard Baxter, The Practical Works of Richard Baxter, volume 1, reprinted from the 1846 edition published in London by George Virtue (Morgan, PA: Soli Deo Gloria Publications, 2000), 1.3: 721.

22 William Haller, The Rise of Puritanism (New York: Harper, 1957), 175.

PERICHORESIS $11.2(2013)$ 
or appeal to the certainties only Scripture could supply. Cartwright had written that,

The natural corruption which is in us hath blotted out all that beautiful image of God... instead thereof set another deformed and ugly image of ignorance and profanenes... We deny not but that we have the natural power to will or nill, choose or refuse, but we deny that by the natural power of our will unreformed and unrenewed we are able to will or choose any good or nill or refuse any $\sin$, especially as it is $\sin .^{23}$

Nevertheless, what restrained Cartwright from an unbridled spiritualised hermeneutic such that Scripture was self-interpreted by no other authority than their God-breathed character, was his own university-trained background. Cartwright was himself bound to accept the logic of his own desire for a highly educated ministry therefore rational discourse had to matter. But for Hooker, this was nothing more than the difference between "ability and aptnes". To be sure, our abilities were corrupted, but without "aptnes", not even grace could save us for we then could not know anything of our predicament.

In his introduction to Geoffrey Nuttall's The Holy Spirit in Puritan Faith and Experience, Peter Lake stresses the multidimensional aspect of Puritanism extending from John Field as revolutionary and radical idealist, to the charismatic experience of the Quakers, and the less obvious ways "... in which the Elizabethan establishment was shot through with Puritan attitudes and personnel”. ${ }^{24}$ Nuttall's assessment of Puritanism is to cast it in terms of the inner spiritual consciousness of believers. In other words, for Nuttall, the power of Puritanism lay in its theological and spiritual emphases which represented the bloom of reformation thought brought about by the accessibility of newly perceived religious freedom and obedience to the law of God that were held to be commanded and revealed through the Scriptures. The enlightenment of the individual soul through the direct disclosure and revelation of the divine will in the Scriptures made effective by the inner work of the Holy Spirit resulted in transformed and converted lives, from a disposition of rebellion against the law of God to one of personal obedience to it. Nuttall writes:

... the Puritans' conviction may be measured by our ability to see their political life, or at least their political ideals, in the way they saw these, as springing directly from the spiritual principle which was central to their faith and experience... if we turn in again towards the centre, and observe the way in which, both personally and socially, the doc-

Taken from Thomas Cartwright, A confutation of the Rhemist translations, glosses, and annotations on the New Testament (Leyden, 1618), quoted in Peter Lake, Moderate Puritans and the Elizabethan Church (Cambridge: Cambridge University Press, 1982), 311, n. 16.

24 Geoffrey F. Nuttall, The Holy Spirit in Puritan Faith and Experience (Chicago: The University of Chicago Press, 1992), xiii.

PERICHORESIS 11.2 (2013) 
trine of the Holy Spirit controlled their devotional life... [Puritanism] has evinced itself to be a movement towards immediacy in relation to God. Men felt keenly that it was insufficient to believe in the gospel simply as a true story of what happened once long ago. If the gospel were to be powerful and saving, it must be realized as affecting the believer now and particularly: the word must be very nigh, in the mouth and in the heart. In Baxter's words: "An historical belief, which is true in its kind... you may come to by rational persuasions, without special grace: but not that deep and firm belief, which shall carry over the will effectually to God in Christ, and captivate the whole man into obedience of his will". ${ }^{25}$

The profound grasp of the centrality of the Holy Spirit as the determinant for Christian knowledge, truth, and personal assurance had come from Calvin. And it had also come from Aquinas and Hooker. While the centre of Calvin's theology at first sight is the glory of God in creation and redemption, the predestined choice of God's elect, and the Scriptures as the centre of revealed knowledge, it is Calvin's pneumatology that constitutes the binding principle of his theology. This is taken up and developed by Hooker and stressed by Owen and Baxter. It is inherently likely that Owen and Baxter had read Hooker. Indeed Debora Shuger has shown that Baxter explicitly refers to the Lawes, alluding to the sermon on Habbakuk and, as I have suggested, to Hooker's connection between grace and reason. However, although Baxter's attitude to reason and the ground of authentic belief (which was Baxter's latter anxiety-the failure of belief itself, not the question of doubt) follows Hooker very closely, Shuger points out that he missed the Aristotelian formulation of the problem. That is, faith finds its context legitimately within sense perception (subjectivity) because the things divine are least accessible (not inaccessible) to reason. ${ }^{26}$ But by the late seventeenth century, the centre of gravity had moved towards Enlightenment concerns over the supremacy of evidence.

\section{Conclusion}

Richard Hooker's relationship with his Puritan adversaries is usually characterised as unyielding. Although his commitments to the Prayer Book and Settlement are clear, there are moments in the Lawes where Hooker appears to be remarkably conciliatory particularly on the question of ordination and the episcopacy. Baxter and Owen both argue for the life of the mind and a defensible epistemology that neither rejects the role of spiritual wisdom and discernment nor the crucial diChicago Press, 1992), 134f.

26 Debora K. Shuger, "Faith and Assurance", in A Companion to Richard Hooker, volume 8, ed. by W. J. Torrance Kirby, Brill's Companions to the Christian Tradition (Leiden: Brill, 2008), 24850 .

PERICHORESIS $11.2(2013)$ 
mensions of grace in overcoming noetic failure, nor the place of nature in human discourse and inquiry.

The immediacy of spiritual experience of which Nuttall describes found full effect among Quakers in the interior life of personal devotion and charismatic worship. Notwithstanding the cautions of Baxter and Owen, the centrality of the Spirit was an experiential and sensory pole around which the "godly" could identify each other. It filled the gap which the rationality of established religion left too much room for the structural complacency that dissent sought to rectify. Geoffrey Nuttall prefers to think in terms of a Puritan mysticism, largely overshadowed by their stern depiction as hostile to art and imaginative piety. Yet he argues that this piety, even if “... Puritans kept an active and firm control of their personalities, allowing small place for relaxation or passivity... [it was] a piety which was essentially a movement towards immediacy in communion with God... it is evident that the type of experience defined was keenly desired and gladly welcomed by at least the more radical among the Puritans". ${ }^{27}$ This itself is characteristic of Hooker in his insistence on right reason and the goal of participation in the life of God transcending the limitations of pious human exertion. If the later Puritans as represented by Richard Baxter and John Owen did not follow Hooker, they sound very much like him.

\section{Bibliography}

Baxter, Richard. The Practical Works of Richard Baxter, volume 1. Reprinted from the 1846 edition published in London by George Virtue. Morgan, PA: Soli Deo Gloria Publications, 2000.

Brydon, Michael. The Evolving Reputation of Richard Hooker. An Examination of Responses 1600-1714. Oxford: Oxford University Press, 2006.

Cartwright, Thomas. "A confutation of the Rhemist translations, glosses and annotations on the New Testament". Peter Lake (ed.), Moderate Puritans and the Elizabethan Church, 311, n. 16. Cambridge: Cambridge University Press, 1982.

Haller, William, The Rise of Puritanism. New York: Harper, 1957.

Hooker, Richard. Of the Laws of Ecclesiastical Polity. Attack and Response: A Christian Letter. Volume 4 of The Folger Library Edition of the Works of Richard Hooker. Edited by John E. Booty. General editor W. Speed Hill, 5.17.23-26. Folger Library Edition of the Works of Richard Hooker. Cambridge, MA: The Belknap Press of Harvard University Press, 1982.

Nuttall, Geoffrey F. The Holy Spirit in Puritan Faith and Experience. Chicago: The University of Chicago Press, 1992. 
Owen, John. Pneumatologia. Discourse on the Holy Spirit. Volume 3 of The Works of John Owen. Edited by William H. Gould. London: The Banner of Truth Trust, 1966.

Rehnman, Sebastian. Divine Discourse. The Theological Methodology of John Owen. Grand Rapids: Baker Academic, 2002.

Shuger, Debora K. "Faith and Assurance". A Companion to Richard Hooker, volume 8. Edited by W. J. Torrance Kirby, 248-50. Brill's Companions to the Christian Tradition. Leiden: Brill, 2008.

Stoute, Douglas. "An Anglican Understanding of Ministry and Church Polity in the 16th Century". Consensus 12.1-2 (1986): 81.

PERICHORESIS 11.2 (2013) 